\title{
Clinical variables associated with depression in patients with type 2 diabetes
}

\author{
Mari Cassol Ferreira ${ }^{1 *}$, Camila Piala ${ }^{2}$, Ana Carolina Cadore $^{2}$, Marinez Amabile Antoniolli ${ }^{3}$, Geni Portela Gamborgi ${ }^{3}$, \\ Patrícia Pereira de Oliveira ${ }^{1}$ \\ ${ }^{1} \mathrm{MD}$, PhD - Full professor, Medical course, Universidade Comunitária da Região de Chapecó (Unochapecó), Chapecó, SC, Brazil \\ ${ }^{2}$ Medical Student, Grant Holder with scientific production, Unochapecó, Chapecó, SC, Brazi \\ ${ }^{3} \mathrm{MSc}$ - Full professor, Pharmacy course, Unochapecó, Chapecó, Sc, Brazil
}

Study conducted at Universidade Comunitária da Região de Chapecó (Unochapecó), Chapecó, SC, Brazil

Article received: $3 / 22 / 2014$ Accepted for publication: $10 / 21 / 2014$

*Correspondence: Address: Av Sen Attílio Fontana, 591E Efapi Chapecó, SC - Brazi Postal code: 89809-000 mari.cassol@uol.com.br

Financial support: Fundo de Amparo Social à Pesquisa (Fund for Social Support of Research), regulated by Article 170 of the State Constitution

\section{SUMMARY}

Background: the aim of the study was to evaluate the relationship between type 2 diabetes (T2DM), depression and depressive symptoms and their clinical impact on T2DM.

Methods: the authors evaluated 214 outpatients, 105 with diabetes (T2DM group) and 109 non-diabetics (control group), with ages ranging between 50 and 75 years (T2DM group $65.1 \pm 5.6$ years, control group $63.4 \pm 5.8$ years). Use of antidepressant treatment or score $\geq 16$ on the Beck depression inventory (BDI) was considered depression. Complications of diabetes and total symptom score (TSS) for peripheral neuropathy were reported by patients.

Results: diabetes group had a higher frequency of depression (35.2\%) compared to controls $(21.1 \%)(\mathrm{p}=0,021)$, with 2.4 times increased risk of depression. The presence of depressive symptoms was also higher in T2DM group (mean BDI $9.5 \pm 8.8$ versus $6.9 \pm 6.2 ; \mathrm{p}=0.039$ ). Symptoms of diabetic neuropathy were higher in depressed subjects. The metabolic control and presence of complications in T2DM group were not associated with depression.

Conclusion: T2DM led to an increased risk of depression, but this did not influence the metabolic control or the presence of other complications.

Keywords: diabetes mellitus, depression, diabetes complications, diabetic neuropathies.

\section{INTRODUCTION}

Type 2 diabetes mellitus (T2DM) is a chronic disease with high prevalence, estimated at $9.8 \%$ of the global population. ${ }^{1}$ Several studies have shown an association between T2DM and depression, which is present in 11 to $31 \%$ of diabetic patients. ${ }^{2}$ These individuals have a $24 \%$ higher risk than the general population to manifest depression at some point in life, and this risk may be even higher in those diagnosed with depression in the past. ${ }^{3}$

The association of these diseases appears to be related to worsening of various clinical factors associated with T2DM, such as worse glycemic control, amplification of symptoms ${ }^{4}$ and a higher prevalence of complications. ${ }^{5}$ Furthermore, patients with T2DM and depressive symptoms have worse physical and cognitive performance, ${ }^{6}$ reduced adherence to dietary and drug recommendations, ${ }^{4}$ and worse quality of life. ${ }^{7}$ Such individuals also represent high- er health care $\operatorname{costs}^{6}$ and have an increased risk of mortality from all causes. ${ }^{8}$

Depression has a significant impact not only on clinical outcomes but also on psychological and social factors, and is connected with gradual worsening of health status $^{9}$ and accelerated cognitive decline. ${ }^{10}$ Because of these negative consequences, some clinical guidelines recommend the evaluation of psychological status and depressive symptoms in patients with T2DM. ${ }^{11}$ However, these recommendations are not carried out effectively in clinical practice. The treatment of these comorbidities jointly is increasingly considered essential for the clinical management of these individuals. ${ }^{4}$

In the present study, the authors evaluated the association between depression and depressive symptoms in individuals with T2DM compared to the general population, and the impact of these symptoms on clinical 
and laboratory parameters, and on complications of the disease.

\section{Methods}

This is a cross-sectional study, conducted from September 2012 to September 2013. The sample consisted of 214 outpatients, with 105 diagnosed with T2DM and 109 nondiabetics. Participants eligible for the study group were those aged 55-75 years with a previous diagnosis of T2DM. The control group consisted of individuals of the same age range without diabetes of any cause, and with fasting blood glucose levels below $100 \mathrm{mg} / \mathrm{dL}$, obtained no later than six months prior to the interview. In both groups, mourning (loss of a close friend or family member in the previous year) was considered as an exclusion criterion for influencing the diagnosis of depressive symptoms.

This study was approved by the Committee of Ethics on human research of the Universidade Comunitária da Região de Chapecó. All participants read and signed a free and informed consent.

The presence of depression was determined by the use of antidepressant medications in order to treat depression, confirmed by medical record review; or a score $\geq 16$ on the Beck depression inventory (BDI), which is an instrument used for the purpose of diagnosing depression. The first BDI scale dates from 1961, designed by Beck et al. ${ }^{12}$ Later, changes were made over the years. Currently, it is widely used in research and clinical practice. It has been properly translated and validated for the Brazilian population, ${ }^{13}$ and it has also been validated for patients with T2DM. ${ }^{14}$ The instrument consists of 21 items on symptoms and attitudes, with intensities ranging 0-3. The items refer to sadness, pessimism, sense of failure, lack of satisfaction, guilt, feeling of punishment, self-deprecation, self-accusation, suicidal ideation, crying spells, irritability, social withdrawal, indecisiveness, distortion of body image, inhibition to work, sleep disorder, fatigue, loss of appetite, weight loss, somatic concern and decreased libido.

The $\geq 16$ cutoff score in BDI was adopted to detect depression, while lower scores were considered non-depressed individuals. The cutoff point $(\geq 16)$ showed the best balance between sensitivity and positive predictive value in a diabetic population, identifying more than $70 \%$ of patients with depression with $71 \%$ certainty. ${ }^{13,14}$

Structured interviews were conducted including the following variables: name, gender, age, marital status, education, duration of T2DM, and medicines used. To assess signs and symptoms associated with poor glycemic control, individuals were asked whether or not they presented in recent weeks polyuria, excessive thirst, increased appetite, weight loss, fatigue, blurred vision or infections. The items counted a point for each positive response. The evaluation of T2DM complications has also been performed by means of an interview with the patient's self-report, investigating the presence of cardiovascular disease, cardiovascular events, diabetic retinopathy, foot ulcer or amputation history, and peripheral vascular disease. For the evaluation of peripheral neuropathy, the authors used the Portuguese version of the total symptoms score (TSS), which scores the typical symptoms of peripheral neuropathy (burning, pain, numbness and paresthesia), further classified according to intensity. The diagnosis of neuropathy was determined as a TSS score $\geq 2$.

Anthropometric measurements included height and weight of patients, with calculation of body mass index (BMI) in $\mathrm{Kg} / \mathrm{m}^{2}$. To measure the blood pressure, an aneroid pressure apparatus was used. Plasma concentrations of fasting glucose, glycated hemoglobin, total cholesterol, low-density lipoprotein cholesterol (LDL-c), high-density lipoprotein cholesterol (HDL-c) and triglycerides were searched in electronic medical records, which included tests performed at the municipal laboratory, performed at up to six months prior to the interview. Tests carried out in another laboratory were not accepted.

\section{Statistical analysis}

Data analysis was performed using SPSS software version $20.0^{\circledast}$. The adopted confidence interval (CI) was $95 \%$ with significance level of $5 \%(\mathrm{p}<0.05)$.

For analysis of the qualitative variables, the authors used the chi-square test and the likelihood ratio test. ${ }^{15}$ The comparison of age and BDI scores between groups was performed using Student's t test and Mann-Whitney test, ${ }^{15}$ respectively. The same tests were used to verify the relationship between the characteristics of individuals with the presence of depression.

Odds Ratios (OR) were estimated with 95\% CIs as a measure of association for both univariate tests and multiple analysis.

\section{Results}

Characteristics of individuals in the T2DM and control groups are presented in Table 1. Compared with the control group, individuals in the T2DM group were older $(\mathrm{p}=0.032)$ and less educated $(\mathrm{p}=0.022)$. Previous history of depression did not differ between groups $(\mathrm{p}=0616)$, and was present in $37.3 \%$ of subjects in the T2DM group and in $33.9 \%$ of the non-diabetic population. The same 
occurred with a family history of depression, which was positive in 34 and $44 \%$ of patients, respectively $(\mathrm{p}=0.138)$. The average duration of T2DM diagnosis was $11.6 \pm 8.5$ years. Regarding treatment of this disease, $46.5 \%$ used only oral medication, and the remainder used insulin associated with oral therapy.

TABLE 1 Demographic and clinical characteristics of the T2DM group $(n=105)$ and the control group $(n=109)$.

\begin{tabular}{|c|c|c|c|c|c|}
\hline \multirow{3}{*}{ Variable } & \multicolumn{5}{|l|}{ Groups } \\
\hline & \multicolumn{2}{|l|}{ T2DM } & \multicolumn{2}{|c|}{ Control } & \multirow[t]{2}{*}{$\mathbf{p}$} \\
\hline & $\mathbf{n}$ & $\%$ & $\mathbf{n}$ & $\%$ & \\
\hline Gender & & & & & 0.224 \\
\hline Female & 68 & 64.8 & 79 & 72.5 & \\
\hline Male & 37 & 35.2 & 30 & 27.5 & \\
\hline Age (years) & & & & & 0.032 \\
\hline Average $\pm S D^{*}$ & $65.1 \pm 5.6$ & $63.4 \pm 5.8$ & & & \\
\hline $\begin{array}{l}\text { Median (min.; } \\
\text { max.) }\end{array}$ & $65(55 ; 75)$ & $63(55 ; 75)$ & & & \\
\hline Marital status & & & & & 0.564 \\
\hline Single & 14 & 13.6 & 20 & 18.3 & \\
\hline Married & 67 & 65.0 & 67 & 61.5 & \\
\hline Widowed & 21 & 20.4 & 19 & 17.4 & \\
\hline Education & & & & & 0.022 \\
\hline Illiterate & 13 & 12.5 & 7 & 6.6 & \\
\hline Incomplete primary & 64 & 61.5 & 58 & 54.7 & \\
\hline Complete primary & 13 & 12.5 & 22 & 20.8 & \\
\hline $\begin{array}{l}\text { Incomplete } \\
\text { secondary }\end{array}$ & 9 & 8.7 & 3 & 2.8 & \\
\hline $\begin{array}{l}\text { Complete } \\
\text { secondary }\end{array}$ & 5 & 4.8 & 12 & 11.3 & \\
\hline University-level & 0 & 0.0 & 4 & 3.8 & \\
\hline $\begin{array}{l}\text { Positive history of } \\
\text { depression }\end{array}$ & & & & & 0.616 \\
\hline Yes & 38 & 37.3 & 37 & 33.9 & \\
\hline No & 64 & 62.7 & 72 & 66.1 & \\
\hline $\begin{array}{l}\text { Family history of } \\
\text { depression }\end{array}$ & & & & & 0.138 \\
\hline Yes & 34 & 34.0 & 48 & 44.0 & \\
\hline No & 66 & 66.0 & 61 & 56.0 & \\
\hline
\end{tabular}

*SD: standard deviation.

Compared with the control group, subjects with T2DM had a higher prevalence of depression (35.2 versus $21.1 \%$, $\mathrm{p}=0.021$ ) and higher scores on the BDI (mean $9.5 \pm 8.8$ versus $6.9 \pm 6.2, \mathrm{p}=0.039$ ), with 2.4 times increased chance of depression (OR 2.4, 95CI 1.1-5.0) (Table 2).
TABLE 2 Association and risk of depression between the T2DM group $(n=105)$ and the control group $(n=109)$.

\begin{tabular}{lllllllll}
\multicolumn{1}{c}{ Depression } & & & & & \\
Group & Yes & & No & & OR & $\mathbf{9 5 C l}$ & \multicolumn{2}{c}{$\mathbf{P}$} \\
\hline & $\mathbf{n}$ & $\%$ & $\mathbf{n}$ & $\%$ & & Inferior & Superior & \\
\hline T2DM & 37 & 35.2 & 68 & 64.8 & 2.40 & 1.10 & 5.00 & 0.021 \\
\hline Control & 23 & 21.1 & 86 & 78.9 & 1.00 & & & \\
\hline
\end{tabular}

The associations between glycemic control and lipid control versus depression were tested in the T2DM group. The assessment of glycated hemoglobin showed a tendency to higher values in depressed subjects $(10.9 \pm 17.7$ versus $9.1 \pm 2.5 \%$ ), even though with no statistical difference $(\mathrm{p}=0.478)$. Fasting blood glucose levels $(143.1 \pm 66$ vs. 160.7 $\pm 63.9 \mathrm{mg} / \mathrm{dL})$, total cholesterol $(197.6 \pm 45.5$ vs. $201 \pm$ $50.9 \mathrm{mg} / \mathrm{dL})$, HDL-c $(42.2 \pm 11.4$ vs. $46.5 \pm 13.3 \mathrm{mg} / \mathrm{dL})$, LDL-c $(109.9 \pm 38.1$ vs. $117.5 \pm 33.9 \mathrm{mg} / \mathrm{dL})$ and triglycerides $(314.6 \pm 627.1$ vs. $231.2 \pm 437 \mathrm{mg} / \mathrm{dL})$ did not differ according to the presence of depression ( $p>0.05$ ). Similarly, BMI was not associated with depression $(\mathrm{p}=0.316)$ with a mean of $31 \pm 5.3 \mathrm{~kg} / \mathrm{m}^{2}$ in depressed and $29.7 \pm 6.2$ $\mathrm{kg} / \mathrm{m}^{2}$ in non-depressed subjects. Systolic and diastolic pressure did not differ between depressed and non-depressed subjects ( $p>0.05$ ) either. There was no relationship between greater amount of hyperglycemic symptoms and the presence of depression (mean $3.1 \pm 1.2$ in depressed subjects versus $2.8 \pm 1.6, \mathrm{p}=0.234$ ).

The average score in the TSS questionnaire was higher in depressed subjects (mean $4.4 \pm 3.2$ ) compared to those without depression (mean $3.0 \pm 2.5)(p=0.048)$; however, the presence of peripheral neuropathy did not differ according to this disorder.

The presence of depression and its association with self-reported macrovascular and microvascular complications are shown in Table 3.

TABLE 3 Presence of chronic complications in the T2DM group, between individuals with and without depression.

\begin{tabular}{lllllll}
\multicolumn{5}{c}{ Depression } \\
Variable & Yes & \multicolumn{4}{c}{ No } & P \\
\hline & $\mathbf{n}$ & $\mathbf{\%}$ & $\mathbf{n}$ & $\%$ \\
\hline Cardiovascular disease & & & & & 0.462 \\
\hline Yes & 15 & 39.5 & 23 & 60.5 & \\
\hline No & 21 & 32.3 & 44 & 67.7 & \\
\hline & & & & & (Continue)
\end{tabular}




\begin{tabular}{|c|c|c|c|c|c|}
\hline $\begin{array}{l}\text { Previous cardiovascular } \\
\text { event }\end{array}$ & & & & & 0.600 \\
\hline Yes & 12 & 38.7 & 19 & 61.3 & \\
\hline No & 24 & 33.3 & 48 & 66.7 & \\
\hline Retinopathy & & & & & 0.063 \\
\hline Yes & 17 & 47.2 & 19 & 52.8 & \\
\hline No & 19 & 28.8 & 47 & 71.2 & \\
\hline Nefropathy & & & & & 0.186 \\
\hline Yes & 6 & 54.5 & 5 & 45.5 & \\
\hline No & 30 & 32.6 & 62 & 67.4 & \\
\hline Peripheral vascular disease & & & & & 0.154 \\
\hline Yes & 14 & 45.2 & 17 & 54.8 & \\
\hline No & 22 & 30.6 & 50 & 69.4 & \\
\hline Neuropathy & & & & & 0.348 \\
\hline Yes & 25 & 39.1 & 39 & 60.9 & \\
\hline No & 12 & 30.0 & 28 & 70.0 & \\
\hline
\end{tabular}

\section{Discussion}

The results of this study revealed that the diagnosis of T2DM is associated with a 2.4 times increased risk of depression compared to people without diabetes. This risk was close to that found by an important meta-analysis, ${ }^{2}$ which showed a 2 -fold greater chance of depression. However, the risk was lower to that found by a large cross-sectional study with more than 3,000 participants aged over 30 years, in which T2DM was associated with a 4.3 times greater chance of depression. ${ }^{17}$ The prevalence of this disorder found in this series is slightly higher than that reported in a meta-analysis by Anderson et al., which revealed depression in $11-31 \%$ of diabetic patients. Similarly, another Brazilian study found a prevalence of $18.6 \%$ in individuals with T2DM. ${ }^{18}$ Similar results were reported in a recent meta-analysis involving more than one hundred thousand participants, which revealed that individuals with T2DM have a $24 \%$ higher risk of developing depression, ${ }^{3}$ consistent with the results demonstrated in this sample: diabetes is a risk factor for depression.

During the last 30 years, increasing evidence has shown that depression is an important comorbidity related to diabetes, ${ }^{19}$ and that the combination of these diseases seems to affect the clinical management of T2DM. Ciechanowski et al. ${ }^{4}$ noted that the number of individuals with glycated hemoglobin levels greater than $8 \%$ was higher among the depressed. Depression is associated with hyperglycemia in patients with diabetes, with a still unclear mechanism and uncertain direction. ${ }^{20}$
Other authors also reported that patients with T2DM and depression have higher glycated hemoglobin levels compared to people without depression. ${ }^{18}$ However, in this study, glycated hemoglobin levels were not associated with the presence of depression, in contrast to most of the evidence from the literature. Another study also previously suggested that blood glucose levels tend to be higher in depressed individuals, despite the lack of significant differences according to the presence of depression. ${ }^{21}$ The existing literature data are still inconsistent with respect to the relationship of depressive symptoms and poor glycemic control.

Researchers have also shown that depression can be associated with an increased risk of complications from diabetes. A meta-analysis, including 27 studies, found a positive association between depression and diabetes complications, both macrovascular and microvascular. ${ }^{22} \mathrm{An}$ other review, longitudinal-based, revealed that, over a period of five years, patients with major depression and diabetes mellitus had a risk $36 \%$ higher of developing advanced microvascular complications such as nephropathy or blindness, and a risk $25 \%$ higher of developing advances macrovascular complications, such as myocardial infarction and stroke. ${ }^{5}$ In this study, the presence of macrovascular and microvascular complications was not associated with the presence of depressive disorder.

The presence of symptoms of diabetic neuropathy, in this case, was significantly higher in subjects with depression. In the past, some authors have already observed that neuropathy symptoms (pain, instability, decreased sensation in the feet) are associated with depressive symptoms. ${ }^{23}$ Additionally, this same study provided evidence that the presence of depression is associated with the severity of diabetic neuropathy. Individuals with diabetic neuropathy symptoms present worse quality of life, possibly due to more depressive symptoms and greater severity of pain. ${ }^{24}$ Another important correlation found by some authors is the presence of foot ulcers and depressive symptoms - people with these symptoms showed a 2 -fold higher risk of diabetic foot ulceration. ${ }^{25}$ In this study, there was no significant association between these conditions. This was due to the fact that the number of individuals with diabetic ulcers was very small, making it impossible to compare.

\section{Conclusion}

The presence of T2DM was associated with an increased risk of depression and depressive symptoms. Furthermore, these patients had more symptoms of diabetic neuropathy. The significant risk of depression among indi- 
viduals with T2DM in this study population is an important finding, given the increasing rates of T2DM and its clinical and public health implications. The authors believe, therefore, that the assessment of depressive symptoms should be part of the overall control of the patient with T2DM, aimed at comprehensive treatment in order to reduce any consequences.

\section{ACKNOWLEDGMENTS}

The authors thank the State of Santa Catarina that, through the Fundo de Amparo Social à Pesquisa (Fund for Social Support of Research), financially supported this research, regulated by Article 170 of the State Constitution.

\section{Resumo}

Características clínicas associadas à depressão em pacientes com diabetes tipo 2

Objetivo: avaliar a relação entre diabetes mellitus tipo 2 (DM2), depressão e sintomas depressivos e seu impacto no controle clínico do DM2.

Métodos: foram avaliados 214 pacientes ambulatoriais, 105 com DM2 e 109 não diabéticos, com idade entre 55 e 75 anos (grupo DM2 65,1 $\pm 5,6$ anos e grupo controle $63,4 \pm 5,8$ anos). Considerou-se depressão o uso de tratamento antidepressivo ou escore $\geq 16$ no inventário de Beck (BDI). Complicações do DM2 e escore total de sintomas (TSS) para neuropatia periférica foram questionados aos pacientes.

Resultados: o grupo DM2 apresentou maior frequência de depressão $(35,2 \%)$ em relação aos controles $(21,1 \%)$ $(\mathrm{p}=0,021)$, com um risco 2,4 vezes maior de apresentar depressão. A presença de sintomas depressivos também foi superior no grupo DM2 (média BDI 9,5 $\pm 8,8$ versus $6,9 \pm 6,2 ; \mathrm{p}=0,039)$. Os sintomas de neuropatia diabética foram superiores nos depressivos. O controle metabólico e a presença de complicações no grupo DM2 não foram associados à depressão.

Conclusão: o DM2 determinou um maior risco de depressão; porém, essa associação não influenciou o controle metabólico e a presença de outras complicações da doença.

Palavras-chave: diabetes mellitus, depressão, complicações do diabetes, neuropatias diabéticas.

\section{References}

1. World Health Organization. World Health Statistics. 2012. [citado set 2013]. Available at: http://who.int/gho/publications/world_health_statistics/2012.
2. Anderson JR, Freedland KE, Clouse RE, Lustman PJ. The prevalence of comorbid depression in adults with diabetes: a meta-analysis. Diabetes Care. 2001; 24(6):1069-78.

3. Nouwen A, Winkley K, Twisk J, Lloyd CE, Peyrot M, Ismail K, et al. Type 2 diabetes mellitus as a risk factor for the onset of depression: a systematic review and meta-analysis. Diabetologia. 2010; 53:2480-6.

4. Ciechanowski PS, Katon WJ, Russo JE, Hirsch IB. The relationship of depressive symptoms to symptom reporting, self-care and glucose control in diabetes. Gen Hosp Psychiatr. 2003; 25(4):246-52.

5. Lin EHB, Rutter CM, Katon W, Heckbert SR, Ciechanowski P, Oliver MM, et al. Depression and advanced complications of diabetes: A prospective cohort study. Diabetes Care. 2010; 33(2):264-9.

6. Edege LE. Diabetes, major depression, and functional disability among U.S adults. Diabetes Care. 2005; 27(2):421-8.

7. Grandy S, Chapman RH, Fox KM. Quality of life and depression of people living with type 2 diabetes mellitus and those at low and high risk for type 2 diabetes: findings from the Study to Help Improve Early evaluation and management of risk factors Leading to Diabetes (SHIELD). Int J Clin Pract. 2008; 62(4):562-8.

8. Van Dooren FEP, Nefs G, Schram MT, Verhey FRJ, Denollet J, Pouwer FO. Depression and risk of mortality in people with diabetes mellitus: a systematic review and meta-analysis. PLOS one. 2013; 8(3):57058.

9. Moussavi S, Chatterji S, Verdes E, Tandon A, Patel V, Ustun B. Depression, chronic diseases, and decrements in health: results from the World Health Surveys. Lancet. 2007; 370(9590):851-8.

10. Sullivan MD, Katon WJ, Lovato LC, Miller ME, Murray AM, Horowitz KR, et al. Association of Depression With Accelerated Cognitive Decline Among Patients With Type 2 Diabetes in the ACCORD-MIND Trial. JAMA Psychiatr. 2013; 70(1):1041-7.

11. International Diabetes Federation (IDF). Global guideline for type 2 diabetes (2005). Clinical Guidelines Task Force. [citado set 2013]. Available at: http:// www.idf.org/webdata/docs/IDF GGT2D.pdf.

12. Beck AT, Ward CH, Mendelson M, Mock J, Erbaugh J. An inventory for measuring depression. Arch Gen Psychiatry. 1961; 4:561-71.

13. Andrade L, Gorenstein C, Vieira Filho AH, Tung TC, Artes R. Psychometric properties of the Portuguese version of the State-Trait Anxiety Inventory applied to college students: factor analysis and relation to the Beck Depression Inventory. Braz J Med Biol Res. 2001; 34(3):367-74.

14. Lustman PJ, Clouse RE, Griffith LS, Carney RM, Freedland KE. Screening for depression in diabetes using the Beck Depression Inventory. Psychosom Med. 1997; 59(1):24-31.

15. Kirkwood BR, Sterne JAC. Essential medical statistics. 2.ed. Massachusetts: Blackwell Science, 2006.

16. Hosmer DW, Lemeshow S. Applied logistic regression. 2.ed. New York: Wiley, 2000.

17. Mezuk B, Johnson-Lawrence V, Lee H, Rafferty JA, Abdou CM, Uzogara $\mathrm{EE}$, et al. Is ignorance bliss? Depression, antidepressants, and the diagnosis of prediabetes and type 2 diabetes. Health Psychol. 2013; 32(3):254-63.

18. Papelbaum M, Moreira RO, Coutinho W, Kupfer R, Zagury L, Freitas S, et al. Depression, glycemic control and type 2 diabetes. Diabetol Metab Syndr. $2011 ; 3(1): 26$.

19. Groot M, Kushnick M, Doyle T, Merrill J, McGlynn M, Shubrook J, et al. Depression among adults with diabetes: prevalence, impact, and treatment options. Diabetes Spectr. 2010; 23(1):15-8.

20. Lustman PJ, Anderson RJ, Freedland KE, De Groot M, Carney RM, Clouse RE. Depression and poor glycemic control: a meta-analytic review of the literature. Diabetes Care. 2000; 23(7):934-42.

21. Engum A, Mykletun A, Midthjell K, Holen A, Dahl AA. Depression and diabetes: A large population-based study of sociodemographic, lifestyle, and clinical factors associated with depression in type 1 and type 2 diabetes. Diabetes Care. 2005; 28(8):1904-9.

22. Groot M, Anderson R, Freedland KE, Clouse RE, Lustman PJ. Association of depression and diabetes complications: A meta-analysis. Psychosom Med. 2001; 63(4):619-30.

23. Vileikyte L, Leventhal H, Gonzalez JS, Peyrot M, Rubin RR, Ulbrecht JS. Diabetic peripheral neuropathy and depressive symptoms: the association revisited. Diabetes Care. 2005; 28(10):2378-83.

24. Moreira RO, Amâncio APRL, Brum HR, Vasconcelos DL, Nascimento GF. Sintomas depressivos e qualidade de vida em pacientes diabéticos tipo 2 com polineuropatia distal diabética. Arq Bras Endocrinol Metab. 2009; 53(9):1003-11.

25. Williams LH, Rutter CM, Katon WJ, Reiber GE, Ciechanowski P, Heckbert $\mathrm{SR}$, et al. Depression and incident diabetic foot ulcers: a prospective cohort study. Am J Med. 2010; 123(8):748-54. 